\title{
National Security, Good Governance and Integration in Nigeria since 1999: A Discourse
}

\author{
Dr. Ahmed Adam Okene \\ Professor/Visiting Scholar \\ College of Arts and Sciences, Universiti Utara Malaysia \\ 06010 Sintok, Kedah, Darul Aman, Malaysia \\ E-mail: ahmedokene2001@yahoo.com, ahmadokene@uum.edu.my
}

Received: May 6, $2011 \quad$ Accepted: June 11, $2011 \quad$ Published: October 1, 2011

doi:10.5539/ass.v7n10p166 URL: http://dx.doi.org/10.5539/ass.v7n10p166

\begin{abstract}
At its $50^{\text {th }}$ Independence Anniversary in October 2010, Nigeria still grapple with serious national insecurity, ethno-communal conflicts and lacking socio- cultural integration and appreciable material development. Though Nigeria's current malaise can be traced to, among many other factors, the despotic nature of colonial rule, misrule of autocratic military regimes of the past and the general bad political leadership that entrenched unpopular policies, Nigeria need to invest massively on education and institute good governance that uphold the rule of law, accountability, protection of human rights, free and independent electoral systems and forbid evils in order to join the global comity of nations. In addition, the country can come out of the present predicament in which kidnapping and drug trafficking have become norms by waging an unselective war on corruption, establishing effective Agency for social mobilization and character reorientation, and entrenching principles of "Multiple Identities' and 'Unity in Diversity". Above all, the country needs to modernize its security bodies to meet global challenges and benchmarks just as Nigerians must accept the country as theirs and therefore abide by public rules, be patriotic, uphold good neighbourliness and always preferring the national interests to selfish ambitions and personal greed. However, the onus to implement these palliatives is not only with the scholars whose tasks undoubtedly, have become more demanding than hitherto but particularly with the politicians, advisors, policy makers and administrators of the Nigeria polity.
\end{abstract}

Keywords: Integration, Good governance, Citizenship, Multiple identity, Trafficking, Reorientation, Authoritarianism, Embezzlement, Restiveness

\section{Introduction}

Nigeria is at the cross road. Though it returned to democratic governance in 1999, experiences so far have shown that Nigeria harvest reverses in its socio-political, material and diplomatic realms. Nigeria and Nigerians have become more fragmented than hitherto. Unfortunately this assertion become apparently accentuated with the consequences of the April 2011 general elections which created more cleavages rather than integration of the various social forces and installation of progressive political leadership. Electioneering campaigns and voting pattern of that elections were largely based on ethnicity, sectionalism, religion and other primordial ties. The nature of the political structures bequeathed by the British colonial masters, the inability of the first generation leaders of Nigeria to manage the challenges that accompanied independence and the rapacity of the first generation military officers among other factors, led to the civil wars of 1967 to 1970 and the undevelopmentality which the country continue to witness.

However, fifty years after independence from British despotism, Nigeria has not positively improved in education, health, social security, political administration and infrastructural provisions. In this situation, insecurity manifesting itself in ethno-religious cleavages, rapacious mismanagement of commonwealth, armed robbery and border banditry, cyber fraud, illegal alien influx, currency counterfeiting, human trafficking and high profile murder have become norms of daily life. Though violence is a common feature of a developing economy, especially cities where socio- structural material imbalances are pervasive, the lack of proactiveness on the parts of leadership and security apparatuses is indubitably Nigeria's trait. 
The prevalence of light arms trafficking, pervasive corruption and financial mismanagement are manifestation of failure of national security, minus for democracy, acute signs of lack of development and obvious signs of a state moving towards failure. In an era of globalization where crime and criminality have become trans-territorial that could be 'scientifically' exported, Nigeria's criminality is also globalised. Thus, Nigerians are involved in money laundry, shops' break in and kidnapping among others, in the West and Asia. United Kingdom, United State, Malaysia, Taiwan, Thailand and China are few of the countries where Nigerians are known for high level crimes. Instead of national integration in an environment of democratic consolidation, Nigeria is harvesting systematic national disintegration in polity and in economic imperatives. All these meant insecurity, threat to peaceful coexistence and mitigation of democratic governance. This paper discusses these entire scenarios in historical perspective and positioned that if Nigeria must move ahead in political stability, material development and geo political integration certain patriotic decisions and developmental programmes must be upheld and executed.

In this vein therefore, to address the ills, leadership must be well designed and cultivated. Leadership must be consistently focused, purposeful, visionary and exemplary. It must support openness and accountability; political leadership in Nigeria should be just taking the entire Nigeria's geo politics as its area of influence and material transformation and development. On the other hand, followership must be constructively cultivated. It should be proactive and dutiful. More so, with huge revenue coming in daily from its supply of 2.2 million barrels of petroleum, high population size of over 150 million people of all categories capable of providing undistorted consumers' markets and production forces and indeed, vast areas of investment in education, agriculture, healthcare and telecommunication, Nigeria is a potential productive contender and economic giant in global political economy. In the same vein, there is the need to develop a financial sector that is doubly geared towards providing investment avenues for big and small investors, and improvement in the standard of living of the Nigerian citizenry. These are challenging to all stake holders of the country particularly policy makers and political leaders.

\subsection{Definition of Terms and Concepts}

It is pertinent here to define some key concepts used in this work in order to make the discussion fully comprehensive within its philosophical constitution of analysis.

\subsubsection{National Security}

Security is the state of being secured or free from danger and risk. It is a situation where either an individual, social group or geo-political entity is protected against any form of danger, espionage or attack of any sort, internally or externally. Though scholars often dissect security into several components, this work's interest is on National Security and those officials saddled with maintaining the security (Security Operatives) in Nigeria. In this context therefore, National security implies the ability of Nigeria country to protect and develop itself, promote its cherished interest, legitimate values and enhance the standard of living and well being of its people, guests and visitors. It is also to Imobighe (1990), an absence to those tendencies which could undermine internal cohesion and corporate existence of the state and its ability to maintain its vital institutions for the promotion of its core values and socio-political and economic objectives, as well as meet the legitimate aspirations of the people.

Furthermore, security could also easily be discussed in conjunction with threat to, and doctrine of, security. While threat to security refers to any act that has the potential of undermining the peace, stability, positive coexistence and progress of the state thereby constituting obstacles to the political and material aggregation, doctrine of security is the articulation of the fundamental principles that governs the management of security which normally flow from the states' ideology or philosophy of public affairs (Okene, 2008). The individuals mandated by law to ensure security are Security Operatives while the style, modems, models and methodology they used is generally termed Operations.

Apart from the state security, there are the Nigerian Police Force, the Nigerian Armed Forces and the Nigerian Intelligence Agency (NIA) who are also saddled by the law to protect lives and properties of Nigerians and their guests in varying degrees. Other parastatals agencies and organizations which also provide security but at a lesser degree compared to those mentioned above are Nigerian Custom Services, Nigerian Immigration Services, Standard Organization of Nigeria, Nigerian Civil Defence Agency, Central Bank of Nigeria and Nigerian Prisons Services.

In order to function very well and meet their highly herculean objectives, those organs tasked with security provision use varieties of methods and means. National security outfits should invest considerably and effectively in re-engineering the services. In a converse order, they should also involve in what is professionally known as "Operations Security" where an analytic processes are used to deny adversary sensitive information - both classified and unclassified - concerning friendly institutions and capabilities by identifying, controlling and 
protecting indicators associated with planning processes and operations. The system of governance through which the people are secured in Nigeria and now globally recognize is Democracy. Nigeria operates democracy and therefore, National security should operate in a democratic Nigeria; securing its principles, cardinal institutions, the officials who operate the system and indeed the citizens upon whom the system governs.

\subsubsection{Democracy and Good governance}

Democracy construes man as the centerpiece, focal point and compact core of its body of operation. Power of representation, enacting of law and political authority belong to the people collectively. Democracy is characterized by multi-party system, electoral competition, respect of fundamental human rights and equality before the law, rule of law, accountability of the elected officials to the electorates through the mechanism of representation and civilian control over the military and other Security Services (Ake, 1999). Democratization in Nigeria started during the British Colonial rule especially after the Second World War when Colonial authoritarianism was deliberately relaxed giving way to some degrees of freedom in expression, association and partisan politicking. In the post-colonial period until 1999, democratization characterized by series of political transitions and toleration of some basic human rights were designed and implemented by despotic military regimes. Scholars have argued years after the return of democracy on whether the experience so far from 1999 to date is full democracy or mere transition to civil democracy (Oyavbaire, 2001).

Due to its glaring shortcomings especially in Africa, democracy has been exploited to foist on the people, bad governance, wanton corruption, perverted despotism and sectionalism. Nigerians have witnessed all these evils since 1999. Thus, it is time to talk of developmental democracy. In other words, democratic worth and positive impact are measured by the degree of its provision of good governance and development in all spheres. Democratic good governance is directly linked to the provision of public goods and utilities, accountability, transparency, supremacy of the rule of law, a diminution of corruption in governments, egalitarian economic arrangements and effective protection of human rights. This is vital to this paper because without good governance and development in democracy, National Security will face more daunting governance problems and herculean challenges that could manifest themselves as we are currently witnessing in disintegrative ethno-religious conflagration, ethno- political militancy, civil unrest and kidnapping in the inland environment and international waterways. Thus, scholars like Robert McNamara (1968), Diamond (1996) and Okene (2008) have linked National security with positive National integration and development, and both with the society.

In all ramifications therefore, Nigerian National Security should be interested not just on bringing to book those violating the constitution and other dysfunctionalties within and without the country as they affect the nation and its citizens but on those variables that precipitate violation of norms. High sense of duty should make the Security to be concerned with food security, economic security, domestic order, educational growth, old age security, national disaster security, job security, environmental security and comprehensive human development and general constructive integration.

\subsubsection{Integration}

On its own, Integration is the satisfaction of the various components of a social polity with regard to justice, fairplay, equitable distribution of resources and ability to access the accruing national opportunities. To J. Coleman (1064) and Bienen (1986), integration is the progressive lessening of ethnic, cultural and regional tensions and discontinuities in the process of creating a homogenous political community. Leonard Binder conceptualizes integration from socio-psycho paradigm when he states that integration involves the creation of a high very level of mental and physical comprehensive(Binder, 1964). In the same vein, integration could be applied separately and in group to either geo-polity like territory, nationality, or socio-psychological imperatives like value system, social behaviour and group category like elite and mass. In this realm therefore, integration could manifest among social beings living in a geo-political entity and should necessarily lead to trust, communal harmony, aggregation of material development and common constructive political objective(s).

However in a mega conception, Ali Mazrui (1972) clarifies areas in which integration work. These are:

a. the fusion of norms and cultures;

b. promotion of economic interdependence;

c. the narrowing of gap between the elite and the masses, the urban and the rural areas, rich and poor;

d. equitable resolution of emergent crises and conflicts; 
e. the sharing of mutual experiences so that people can discover that they have undergone some important experiences together.

Generally speaking therefore, integration is the feeling of the history of togetherness and high sense of community in all sectors. In a way integration is development in all ramifications of human and physical endeavours. The final objective of integration is that society is lived, guided, guarded and administered with tolerable minimum conflicts.

\section{Brief Historical Survey}

Nigeria as an official entity came into existence when the British began to occupy the Nigerian areas from the late $19^{\text {th }}$ century and it became crystallized with the amalgamation of the Northern and Southern protectorates in 1914. However, areas of Nigeria had co-existed for several centuries before the advent of British colonialism. They have traded in goods and services as good neighbours. The factors of trade, commerce, cultural diffusions, education, adventures and missionary activities have integrated the various peoples of the area now known as Nigeria long before the British invasion. They had also gone to wars and inter border conflicts which indeed helped in the long term in cementing relationship and in creating more city- states and mega settlement areas.

Also, there were migrations of people across all parts of areas of Nigeria before 1900. From the southern end of the Cameroon Mountain, like Chad withstood at the centre of Kanem Borno Empire; to the north, the Hausa plains which stretched to the Asben Mountain; to the western area of modern Nigeria, was the huge plain with no fixed barriers - all of which encouraged movements within the ecological zone and boosted cultural and ideological intercourse. The complementarities of the Sudan belt and the forest-zone with the intervening transitional middle Belt, to Ade Ajayi and Alagoa (1999) encouraged the movement of peoples, goods and ideas north and south across the various zones of the areas of Nigeria. The trans-Saharan trade has many aspects to its existence. But because the trade on it of many Sudanic states were majorly based in part, on products from the forest zone and the Niger-Benue Confluence area, many southern polities and peoples have, at different times before the British invasion of Nigeria area, expanded northwards or exerted pressure on groups to the north. For instance, Jukun Kingdom in the Middle Belt, modern Central Nigeria at different times in the $17^{\text {th }}$ and $18^{\text {th }}$ centuries made incursions northwards as far as Kano and Katsina; Benin Kingdom and Igbo peoples to the east exerted pressures on peoples and polities of the immediate north in the presence Niger-Benue Confluence area (Ajayi \& Alagoa, 1999).

There were also the diffusion and integration that were engendered by the unity of river system in the Nigerian areas. Lower Niger south of Bussa rapids, the Benue, its tributaries and the enormous Delta spreading out into several creeks and lagoons provided the platform of the unity of waterways which were capitalized upon by the people to network productive relationships. The river networks provided routes of contact between peoples cutting across the north and south axis and supplement it. Thus, geographical settings and location, agricultural practices, artisanship (Iron, Bronze, gold, Salt), Niger-Benue as a courier of trade (trans-Sahara routes and trade) and indeed the slave trade created avenue for the people of Nigerian areas to interact and integrate.

Having stated the above obvious, it should be admitted that Nigeria in the current setting have factors that are not only divisive in themselves but particularly can be exploited for divisive purpose and disintegrative interest. Nigeria is a deeply pluralistic society. The country is known to have many ethnic and sub-ethnic groups. Indeed Nigeria is one of the most ethnically diverse countries of the world with well over 200 ethno-linguistic divisions (Kirk Greene, 1964). Indeed, by 1976, linguists identified 394 distinct linguistic groups within Nigeria (Usman, 2006). Though some of these languages have extinct and severely reduced due to the spread of standardized versions of linguistic dialects, Nigeria has within its territory a substantial number of speakers of three out of the five families of languages found in Africa. Speakers of Afro-Asiatic, Niger-Congo and Nilo-Saharan are well known in Nigeria. Only Khoisan and Indo-Malay are not represented in Nigeria. In addition, Nigeria's 150 million populations make it the $10^{\text {th }}$ most populous nation in the world and certainly the most populous in Africa. It is least surprising therefore, that these ethnic groupings and the highly mismanaged sizeable population are always in perpetual competition, sometimes violently over resources that are sometimes scarce but in most cases abused and misappropriated.

\section{Current Dispensation}

In the current dispensation, Nigerians and Nigerian polity are not properly integrated. Though dysfunctional factors and centrifugal forces which created wedges of wide gap between the peoples had always existed from the colonial period down into post colonial era, the level of socio- political disintegration and diplomatic disarticulation have never been as high as it is presently. Several factors are responsible for this. These include but not limited to the despotic and discriminate nature of British rule; the civil war, prolong era of military rule, 
despotism and dictatorship, high level of illiteracy and poverty, gross maladministration of the civil governments and corrosive degree of corruption among government functionaries and in the Nigeria's general psychic system, sectional irredentism, manipulation of ethnic and religious sentiments and general politicization of all Nigerian issues. Brief analyses of some of these factors will further illuminate the position of this paper.

\subsection{Colonial Despotism}

Colonial rule in general term is autocratic and despotic. In the Nigeria colonial state, the British in addition did employ the strategy of divide and rule system to extort and exploit the citizens. They played either one ethnic or religious group against the other. In the old Zaria emirate, the British is generally believed to have consummated the ruler ship of the Emir of Zazzau (Zaria) over other smaller minorities of the south. Because of this perception, the Hausa-Fulani ethnic people of Zaria in Kaduna then were suspected and perceived as collaborators with the British, even though the reality was more complex than it ordinarily appeared (Toure, 2003). During the British era, this perception led to resistance of these minorities especially the Bajju who embarked on blocking roads, raiding caravans and attacking the Hausa itinerant traders and administrative officers in their areas. Since independence, these minorities have embarked on violent agitation against the Hausa-Fulani led administration. This perception as dysfunctional as it is has led to the Kafanchan crises of 1987, Zango Kataf imbroglio of 1992 and partly the Shariah crises of 2001.

In the old Benue-Plateau division, current crises between the Tiv and Jukun ethnic groups that have consistently defied solutions have also been traced to the colonial policies of the past. The seeds of trouble between the Tiv and the Jukun were drawn in the colonial period because while the British were considered biased in favour of Jukun, they failed to carry out their policies with transparency and consistency. In this vein, while the British on the one hand saw the continuously migration of the Tiv into the Wukari as a threat to Jukun political suzerainty which they indeed maintained, they on the other hand contended that the Tiv were industrious farmers whose farming activities provided the revenue which was essential to maintain Wukari native administration (Okene, 2005). In this same divisive colonial manipulation is what almost become the intractable Ife-Modakeke animosity and bloody wars in Osun state which reached its peak in the period 2003/2004. In this same categorization is the Yoruba- Hausa fighting in Shagamu in Ogun state. In a nutshell, the British rule consummated racism and disharmony in colonial Nigeria and sow the seed of crises which the country have been harvesting in its post independence period. They created divisions among the various groups and instituted the regime of superior and interior status and complexes. The fear of domination boosted on bitter experiences of the past tends to exacerbate rancor, animosity, bitterness and disharmony among diverse ethnic and religious groups.

\subsubsection{Military Dictatorship}

Autocratic military regimes that were unleashed on Nigeria and its people and the consequences of such have also fueled ethno-religious and other identity based conflicts thereby constituting obstacle to integration. By its nature, military misadventure into politics which dominated the political landscape for over three decades out of five decades of its independence had employed all sorts of diabolical devices to control and perpetuate power. The policies of these regimes particularly socio-economic ones have deliberately evoked identity base conflicts. The Babangida's Structural Adjustment Programme (SAP), for instance had profound devastating consequences on the Nigeria's political platform.

Anchored on the devaluation of currency, deregulation of exchange rate, cuts in public expenditure, removal of subsidies on state ;provided services and privatization and commercialization of public enterprises, SAP unleashed on the public heavy external debt burden (from $\$ 19.5$ billion in 1983 to $\$ 30$ billion by 1994), phenomenal rise in inflation and sky-rocketing cost of education and healthcare (Jega, 2003). Coupled with heavy loss of jobs and general insecurity, the negative impacts of SAP caused social tension and protests which manifested themselves in ethno-religious crises as in Kafanchan crises (1987), Zango Kataf (1992), Numan (1988), Hausa-Beron (1987), Tiv-Jukun (1987-92), Hausa-Sayawa of Tafawa Balewa (1991) and host of others which were prevalent during that regime of eight years. These crises like those of the southern Kaduna, Tiv-Jukun, Hausa-Sayawa and Hausa-Bachama were carried over into the current democratic dispensation. Mistrust and mutual acrimony were engendered just as they created wild wide gap between the people even in a common geo-political zone.

\subsubsection{Bad Political Leadership}

However, the greatest cause of threat to integration is the enthronement of bad leadership. Though Nigeria returned to civil democratic rule since 1999, the conduct of affairs so far through presidential democracy has engendered unrepresentative, political authoritarianism, endemic corruption and economic exclusivity. It is instructive to point out that from its outset experts ${ }^{21}$ on political transformation were doubtful of the foundation of Nigeria's current experience. By its policies and patterns of appointments, patronage and provision of essential social and economic 
services, the President Obasanjo's dispensation which spanned 1999 and 2007 was unable to lay a solid foundation for democratic dividends. With its vast human and mineral resources, most of which are in commercial quantities, the desires of its people were harmony, security, peace, better conditions of working for the civil servants and employment. All these were expected to have been realized through the eight years suave and impressive windfall earnings from its major export, the crude oil that gave unprecedented massive monthly revenue flow into the treasures of all country's three tiers of government - Federal, State and Local government. Unfortunately as succinctly put by the late erudite scholar, Bala Yusuf Usman (2006), "those elected to head the governments at all levels in this polity have failed to give the leadership required to put the country on the path to sustained economic recovery and build up and strengthen the public institutions for enduring democratic rule". The failure to use the resources to lay robust political economy during this critical period, according to Tell News Magazine (2005,Vol.23,22-27) published from Lagos, the erstwhile Nigeria's capital and the nation's commercial nerve centre, accentuated wanton insecurity, youth restiveness, unemployment and resultant ethno-religious conflicts that characterized Obasanjo's regime and may take some years to overcome. Some of the Obasanjo's ministers like those of Internal Affairs, Sunday Afolabi, Aviation, Femi Fani-Kayode, Federal Capital Territory, Nasir El Rufai and Energy, Liyel Imoke and Dr. Julius Makanjuoala, former Permanent Secretary of Ministry of Defence are accused of corruption, and are currently standing trial in competent Nigerian courts (Usman, 2006). All these are coupled with the regime's ordering of the invasion of Odi in Southern Nigeria in 2000 and Zaki-Biam in Northern Nigeria in 2002 by the Nigerian military trained by tax payers' money and the high profile assassinations of political notables like Bola Ige in December 2001 and Harry Marshall in March 2003.

During President Umaru Musa Yar'adua's tenure, national budgets were never properly implemented. Though the regime upheld the independence of the judiciary and led a better transparent government as long as Yar'adua was healthy even insisting on returning to the federal coffer all unspent money of the ministries, the vesting of power on selected over ambitious ministers who treated Nigerians with scorn and Nigeria as their fiefdom created dullness in governance. Under Goodluck Jonathan, leadership's inconsistency and lack of proactive and transparent budgetary governance have become hall marks of administration. In what appeared to be a norm of governance under Jonathan, the government set up Presidential Advisory Committee under Retired General Thoephilus Danjuma without constitutional provision and clear cut functions. All these coupled with the confusion that trailed the author ship of the $1^{\text {st }}$ October 2010 Celebration of Independence's Day bomb blast in Abuja the Nigeria's capital had generated new wave of social tension and sectional sentiment long before the April 2011 general elections. Since the October $1^{\text {st }}$ bomb explosion in Abuja, more bombs have rocked Jos and Yenogoa in the Nigeria's North Central and South - South respectively which the government capitalized upon to repress political opponents (Tilde, 2010).

In the same vein, since the beginning of July 2010 when some Journalists were kidnapped, crimes especially targeted political killings have been on the upsurge. The head of Forensic unit of the Economic and Financial Crimes Commission (EFCC), Abdullahi Muazu was cold bloodedly murdered in Kaduna on September $14^{\text {th }} 2010$ in the same way Dr Stanley Uche of Christian Hospital of Aba in southeast Nigeria was murdered after his abductor took the sum of 30 million naira of ransom from his wife (Daily Trust, September $14^{\text {th }} \& 21^{\text {st }} 2010$ ). Though a member of the Nigeria's House of Representatives, Bala Na'Allah suggested death penalty for anybody arrested for kidnapping (Daily Trust, September $14^{\text {th }} \& 21^{\text {st }} 2010$ ), there is the need to tackle the insecurity deluge of the country scientifically. In the run up to the April 2011 general elections, political opponents kidnapped their rivals in some south eastern states like Delta and Rivers just as the electioneering campaigns of prominent parties and notable politicians were conducted under the umbrella of 'obscene monetization' sectional zoning, ethnicity, religion and other primordial based identities (Falana, 2011). The Elections proper was marred with violence and bloodletting, especially in Maiduguri, Borno State, Suleja, Niger State and parts of Delta State (BBC News 2011). Expectedly, the results of the elections, especially the Presidential election was greeted with massive protests and violence, especially in the Northern States that some States like Kaduna, Sokoto, Bauchi and Gombe had to impose curfews to control violence and protect life and properties.

Though the 2011 elections in Nigeria are considered the best since 1999, some Independent Electoral Observers and Civil Society Groups discovered quite significant anomalies at the levels of accreditation, voting and collation which marred and dented the credibility of the Electoral Commission. The Civil Society Election Situation Room (CSERS), a credible Non Governmental Election Organization under internationally acknowledged scholars, Jibrin Ibrahim and Clement Nwankwo reported that the some of the elections, nay the Presidential ones, were characterized by significant instances of underage voting, incidents of massive thumb-printing and unjustified arrest and intimidation of election observers. These anomalies were more prevalent in states of Bauchi, Gombe, Kaduna, Plateau, Taraba, Nasarawa, Rivers, Benue, Delta and Imo (Ibrahim \& Nwankwo, 2011). The reports 
identified the collation process as the weakest link in the election management system in which fraud was perpetuated. Though the voting national average turnover was put at $53 \%$ by the Independent National Electoral Commission (INEC), the country's official electoral body, the international Independent Electoral Observers and Electoral Non Governmental Organizations, states like Abia, Akwa Ibom, Bayelsa, Bauchi, Cross River, Delta, Edo, Enugu, Kaduna, Imo, Plateau and Rivers recorded more than 60\% vote rates (Ibrahim \& Nwankwo, 2011). To CSERS, these figures are suspect that require thorough investigation. The 2011 elections conflict poses serious challenges in the current and future integrative existence of Nigeria. Nigeria missed a great opportunity once again, to use elections to create sense of harmony and integration in the country and to provide purposeful leadership. Indeed, a general election that "should have served the most desired purpose of cementing the fragile unity of our country", to Femi Falana, a legal expert and pro- democracy activist, "has since further divided Nigeria along southern and northern protectorates" (Falana, 2011) as created by the British colonial administration.

The point been made here is that, bad governance and visionless political leadership, and indeed the inability of the successive governments since the return of democracy in 1999 to address fundamental issues of democratic consolidation, health, education, energy, infrastructural provisioning and food, rule of law and fundamental human rights have undermined social and political stability. Bad governance which became accentuated since the last two years has increased the level of poverty and despondency. The Central Bank of Nigeria's Chief, Sanusi Lamido Sanusi (2011) made this traumatizing observation early 2011 when he wrote that 70 percent of Nigerians lives below poverty line, up from 54 percent of the period 2009/2010 financial year. Since this staggering figure included over 12 million youths, mostly educated and potentially productive but unemployed, it means that National economy and growth, security and stability are further threatened.

\section{Attaining National Integration, Good Governance and National Security}

There is no doubt that more than ever before Nigeria needs to put all positive variables on table and advance all productive devices to attain nation al integration, good governance and accountability. Though certain measures have been taken in the past, but most of them have not been effectively applied and as such the country continuously harvests reverses. Therefore, while there is the need to strengthen upon the existing ones, there is the need to urgently implement and infact enforce where required the following measures.

\subsection{Improving Education}

Education has always been a tool of positive integration. The modern dominant structure and curriculum of education has its root traced to British rule in Nigeria. Though it went into several phases and structures, education has remained a tool of advancement and modern economy either domestic or global is driven by knowledge and general education. Though the British, given its history of entrance into the Nigerian scene and her exploitative interest, was cautious, selective and discriminatory in their colonial education, post independence Nigeria polity still grapple with the herculean task of giving appropriate, qualitative, qualitative and economy driven education to the citizenry. The various educational policies, programmes -Nomadic education, Unity school system, Universal Basic Education- philosophy and objectives have not successfully worked. The massive failures in exam bodies, constant strikes in schools and universities and general inertia, poor infrastructural provisioning in the tertiary institutions explain the Nigeria's malaise in this critical sector. There is the need therefore to reform all the sectors of education to make it ethical, civilizational and also globally focused. An educated and indeed knowledgeable person should know his rights and rights of others, and the rights of the society on him. An educated person should know that crises and unwarranted conflicts are obstruction to the development, peaceful co existence and integrative serenity of the society. Qualitative education requires adequate provision of facilities and welfare packages for staff. The various educational bodies and agencies like Universal Basic Education, Primary Education Commission, Joint Admission Management Board, West African Examination Council and National Board for Technical Education and National Universities' Commission should be strengthened, appropriately funded and made to function within universal standards. The Nigerian government should begin the re internationalization of Nigerian universities by selecting at least, two universities per geo-political zone and turning them into highly standard institution through the provision of world class infrastructures and modern teaching aid materials. Though Nigeria requires additional universities to cater for the insatiable taste for higher education, establishing more universities as currently being embarked by the Federal Government is not a priority. What are of paramount importance now in addition to the above are the expansion of universities' facilities and increasing staff welfare. It may consider passing a law to prevent public-civil servants from sending their wards abroad for higher education except for courses and programmes that are not available in Nigeria. This will increase the interest of all in the nature and quality of education available in the country. It will also assist in bringing private funding for the nation's educational sector as it will discourage theft of public resources by public servants to send wards to abroad educating that are available in the country. 


\subsection{Instituting Good governance}

The need and quest for productive and developmental governance is more imperative than hitherto. The current government should go a long way to calm nerves that were provoked during April elections by instituting national reconciliation commission, reconstruction and rehabilitation bodies and providing succor to disabled and displaced citizens. There is the need to institute good governance in all the facet and levels of geo-political administration of Nigeria. Good governance which is ideologically free and neutral should enable the people to choose their leaders and representatives; it should enjoin the leaders to govern with sincerity, through the purview of "enjoying the good and forbidding the evils." Enjoying good implies provision of public goods, utilities, accountability, effective protection of human rights, provision of portable water, good road, sound health facilities, transparency, catering for the disables, children, aged and women empowerment. Forbidding evils include but not limited to combating ethnic irredentism, sectional militancy, eschewing religious manipulation and perverted leadership, waging war against money laundry, human kidnapping and all other activities and programs that threaten free legitimate trade and security of Nigerian citizens and the nation's guests. In addition, there should be an institution of positive measures to ensure easier access to finance for seeking to establish medium, small and micro businesses. In the same vein, the Nigerian government as advised by its apex bank (Sanusi, 2011) needs to redirect public expenditure away from recurrent expenses and unnecessary consumption back to capital projects with the view to impact positively on personal incomes and employment. There is the need to redirect all developmental policies and attention towards agriculture by the provisions of inputs, improved varieties, implements, soft loans and transport and export facilities.

\subsection{Sustaining the War against Corruption}

In addition, there must be an all out war against corruption. The current administration should come out strong against corruption even if to re assure Nigerians and international community, particularly investors and potential multinationals that though the last elections were characterized by massive monetization and bribery of electorates that Nigeria is ready for real business through the purview of global parameters. In this vein for example, top governmental officials should live within their means and the citizens should see it so. Anti corruption crusade must be embracive, non sectional and non selective. Agencies like Independent Corrupt Practices Commission (ICPC), Economic and Financial Crimes Commission (EFCC), etc, should truly be independent in the discharge of their responsibilities. A diminution of corruption in all layers of governance is a cardinal pillar of good governance. As such, Agencies fighting fraud, financial misconduct and public embezzlement should be sincere and honest. A corrupt society as in Nigeria creates discordances, despondency and unemployment, motivate armed robbery, create mutual distrust and acrimony and general disintegration even if slow and systematic. No society can endure for long with a high level of socio-political corruption and theft of common wealth and public resources as presently witnessed in Nigeria. In a country where a whopping sum of $\$ 400$ billion has been reportedly stolen from the coffer of public purse since independence in 1960, the paucity of development and dearth of economic growth is understandably (ThisDay, September $21^{\text {st }}, 2010$ ).

In order for the public to have confidence on the fight against corruption, government functionaries should stop celebrating convicted corrupt citizens for selfish political reason as Jonathan government did when Olabode George was released in March 2011after serving 2 years jailed term for misappropriating more than 100 billion naira tax payers money (Vanguard 2001). In addition, in order to quickly dispense with justice, the Federal Government should set up special courts to try offenders. It means therefore that the government should stop the practice of holding offenders in the detention for a while, then releasing them after awhile through the back door. In all, everyone must be involved in fighting corruption: social groups, NGOs, CBOs, Students' Union, Market women and Artisans' Associations. There should be coalition of all these groups to fight sleazebag and theft of the common wealth.

\subsection{Creating Social Mobilization Project}

There is also the need for massive social mobilization and character reorientation. The history of Nigeria is replete with various social reorientation programmes. These include, Ethical Revolution, Mass Mobilization for Social and Economic Reconstruction (MAMSER), National Orientation Agency, etc. All have not worked partly because they were not conceived with sincerity, their creators did not live within their programmes and in most cases, and the campaigners were not properly equipped. As such there is the need to make social reorientation and character remolding project more ethical and moral. Orientation should have its models, methods, audience and targets. Such reorientation should use local, domestic and scientific approaches to reach its targets. In addition, social mobilization and character reorientation should seek to reconstruct Nigeria's rapidly damaging and indeed battered socio-political and economic values by genuinely emphasizing values that can promote integration, 
cooperation, togetherness, respect for the elders, respect for privacy, support for the less privileged, aged and children, truthfulness and honesty at all times and in all ramifications. In this case, the Federal Government might wish to borrow leave from A Daita Sahu Project that has successfully worked for Kano State since 2003 to reform the citizens' characters and attitudes.

\subsection{Enhancing Positive Citizenship}

The country should also uphold, enhance and entrench the principles of 'Multiple Identities' and "Unity in Diversity". This philosophy is predicated on upholding and emphasizing those values of history, of togetherness, of trade, of cultural assimilation and sense of political unity among the various social forces and groups of Nigeria while at the same time appreciating those fundamentals that make the different group distinct. In this case, common political institution, common constitution and common currency among others, should necessary produce in the people and the country the sense of unity but in diversity. Such sense should produce the platform for economic unity, institutional commonality and socio-practical integration. There is no doubt that the idea is being around in Nigeria for long but bad governance, corrupt leadership and constant manipulation of cleavages have undermined its fertilization as the case of the crises Plateau state in recent time has shown. It is now time to enshrine this philosophy in the Nigeria system and among Nigerians. In the same platform is the fundamental issue of citizenship.

Lack of proper philosophy, principle and modus of citizenry integration in the constitution and other legal framework has created division, disparity, confusion and conflicts in many parts of Nigeria making local champions and ethnic war lords to become "heroes" and "winners" as they convert otherwise harmonious geo-polity and national institutions into centre of ethnic bickering. Proper inculcation of the sciences and philosophy of Ethnic relations" should be able to ameliorate cases of excessive discriminations, pervasive idiosyncrasies and sectionalized "fatherism" have created frustration and disintegration. Inertia, mediocrity and polarization breeds poor rule, poor performance and resultant backwardness. For once, Nigeria should solve its citizenship question. Nigeria should emulate developing economies with the same problems and domesticate their models of solution. China, India, Lebanon and Malaysia have achieved some degrees of success in resolving matters concerning citizenship and ethnic polarization. Nigeria should truly be a developing federated economy with respect for multiculturalism.

\subsection{Reforming the National Security Organizations}

Outside all the above, Nigeria should re positioned the various security organizations. The Nigeria Police Force, the State Security Services and other lesser official security outfits should be equipped with modern gadgets and tools of operation. In the same vein, the welfare of the personnel should be improved upon to measure up to international standards or at least, to equate those of the developing economy. On the job training and professional education should be easily accessed by security operatives. They should be exposed to modern scientific information technology on their fields which should give them edge above criminals. The total collapse of security in face of the sophistication of the current wake of kidnapping and assassination of rival political opponents since the beginning of the parties' primaries, especially those of the People Democratic Party clearly exposes the backwardness, inefficiency and obsoleteness of Nigeria's security system and its operations. Nigeria security apparatuses should be re-invigorated to face this challenge and the challenges posed by the reactionary politicians who always profit by subverting rules through collaboration with corrupt party officials, electoral officers and through the help of thugs and violence. The security should employ the importance of 'Operations Research' in solving the tumultuous problems of security in the country. In doing all these, the security agencies should check the excesses of it chiefs and operatives. The current situation where security chiefs are richer than their agencies should be investigated and checked just as the participation of operatives in crimes that have become more pervasive than hitherto should be stopped by punishing the collaborators. Indeed, corruption that is generally known to be pervasive among the nation's security where officials collaborated with criminals should be ameliorated.

Above all these, Nigerians should be law abiding. It is appreciated that the nation's law are always enforced on the poor and the down trodden at the exclusion of the so called nova riche, just in the same way the poor suffers when corrupt leaders fight over "national cake" and power tussles hiding under sectional umbrella and ethnic interest. Nigerians should be good citizens who apply positive rules to their lives and be their brother's and neighbour's keepers. Nigerians should be proactive in their demand for good governance and accountability. They should fight against ethnicised politics and sectional governance which is currently been foisted on the national psyche. Membership of Non Governmental Organizations (NGOs) and Community Based Organizations (CBOs) should 
be pursued for the progress of the Nigerian people and the country and not to serve the interest of donor countries and agencies whose notions of development and nationhood may not be in the best interest of corporate Nigeria.

\section{Conclusion}

A fundamental function of a modern nation is the defence of its national security and its territorial integrity. National security is the philosophy, principles and a model employed by a sovereign state to protect its core values. In Nigeria, National Security encompasses the philosophies that enable the government to protect and develop itself, promote its cherished interest and maintain its vital institutions for enhanced socio-political and economic objectives and to meet the legitimate aspiration of the people. It also empowers the government to protect its citizen from threats in all ramifications. In other words, national security is closely related to development and they both enhance integration between the various components of the country.

However, every successive government has left the country fragmented than it met it. Threats to life and properties have become accentuated with ethno-religious conflicts, political and ethnic militancy, smuggling and bunkering of resources among others that continue to threaten Nigeria's national security. Even with the entrenchment of democracy since 1999, these malaises have become accentuated. There have been high profile political assassinations and kidnapping that seems to have defied solutions. If Nigeria must ensure security of life and property to bring about the desired national integration, it must improve the quality of education which nevertheless should be both ethical and globally driven. In addition, the country should install egalitarian leadership which should uphold good governance; leadership that should commit itself to fighting evils and corruption. There should be a total social reorientation and attitudinal change to socio-political and economic imperatives. The country also needs to entrench the philosophy of "Multiple ethnicity," Unity in diversity and productive citizenship. Corruption must be fought by all-NGOs, CBOs, Students Union, Market Women and Artisan Associations. Finally the nation's conception of security which protects only those in high political positions should be discarded. National security should secure Nigeria, Nigerians and their guests who are on legitimate sojourn from all domestic onslaught and external incursion.

\section{References}

Ade Ajayi, J.F and Alagoa, E.J. (1999). Nigeria before 1800: Aspects of Economic Development \& Inter-Group Relations. In O. Ikime (Ed.). Ground Work of Nigerian History. (pp. 224 -235). Ibadan Nigeria: Heinemann Educational Books (Nig) Plc for HSN.

Ake, C. (1991). Re Thinking Africa. Africa Journal of Democracy, Winter, Vol. 2, No. 1, pp. $209-221$.

BBC News Nigeria Country Profile. [Online] Available: http://news.bbc.uk/2/hi/africa/country. (19th April 2011)

BBC News Nigeria Elections: Deadly blasts hits Suleja office. [Online] Available: http://www.bbc.co.uk/news/world-africa. (8th April 2011)

Bienen, H. (1983). The State and Ethnicity: Integrative Formula. In V. Olorunsola and D. Pothschild (Eds). State Versus Ethnic Claims: African Policy Dilema. (pp. 100 -126). Colorado: Western Press.

Binder, L. (1964). National Integration and Plural Development. American Political Review, 18(3).

Coleman, J.S. and Rosberg, C.G. (Eds) (1964). Political Parties and Integration in Tropical Africa. Los Angeles: University of California Press, (Chapter1 \& 2).

Diamond, L. (1996). Towards Democratic Consolidation. Journal of Democracy, Vol. 7, No. 3.

Falana, F. (2011). Blame The Reactionary Politicians For 'Operation Wetie' In The North. [Online] Available: http://saharareporters.com/news - blame-reactionary-politicians and http://nmnonline@googlegroups.com (April $\left.21^{\text {st }}, 2011\right)$

Ibrahim, J and Nwankwo, C. (2011). Civil Society Election Situation Room: Final Statement on Presidential Election. [Online] Available: http://www.saharareporters.com/press-release/civil-society-election-situation-room-final-statement-presidential(April 20th, 2011).

Imobighe, T.A. (1990). Doctrines for and Threats to Internal Security. In A. E. Ekoko, and M. A. Vogt, (Eds), Nigerian Defence Policy: Issues and Problems, (pp. 46 -61). Lagos Nigeria: Malthouse Press Ltd.

Jega, A.M. (2003). The State \& Identity Transformation Under Structural Adjustment Programme in Nigeria. In A. Jega. (Ed), Identity Politics Under Structural Adjustment Programme in Nigeria (pp. 26 - 44). Uppsala: Nordiska Afrikainstitutet. 
Joseph, R. (2003). State, Governance and Insecurity in Africa. Democracy and Development: Journal of West African Affairs, Harmattan Edition, Vol. 3, No. 2, pp.7-15.

Kirk Greene, A.H.M. (1969). The Peoples of Nigeria. Journal of African Affairs, No. 262, pp. 4- 17.

Lamido, S.L. Nigeria's High Poverty Level. [Online] Available: http://www.dailytrust.dailytrust.com/index.php?option=comcontent\&view=article\&id=10864:nigerias-high-pove rty-level, (January 30th , 2011)

Mazrui, A. (1972). Cultural Engineering \& Nation Building in East Africa. Evanston: North Western University Press, (Chapter 3).

McNamara, R. (1968). The Essence of Security. Colorado USA: Boulder Press, (Chapter 1).

Okene, A.A. (2005). Managing Ethno-Religious Conflict in Nigeria through Good Governance and Democratic Consolidation. In A. M. Yakubu et al (Eds). Conflict and Crises in Nigeria since 1980, Vol. 2. (pp.209-231). Kaduna Nigeria: Baraka Press \& Publishers Ltd.

Okene, A.A. (2008). Maintenance of Security and Good Governance in Kaduna State: An Assessment of the Period 1999 - 2005. In Ubah, C.N et al (Eds). Studies on Kaduna State, (pp.29-52). Kaduna Nigeria: Nigerian Defence Academy Press.

Suleiman, S. (2011). Contextualzing Protests in Northern Nigeria. [Online] Available:http://suleimansblog.blogspot.com/2011/04/contextualizing. (April 23 $3^{\text {rd }}, 2011$ )

Tilde, A.U. Dr. (2010). Nigeria- The Approaching Violence DISCOURSE 306. [Online] Available http://fridaydiscourse.blogspot.com and mnmonline@googlegroups.com (October $3^{\text {rd }}, 2010$ )

Toure, K.T. (2003). Ethno- Religious Conflicts in Kaduna State. Kaduna Nigeria: Human Rights Monitor, (Chapter 3).

Usman, Y.B. (2006). The Sokoto Caliphate and Nation- Building. In H. Bobboyi, and M. Yakubu (Eds). The Sokoto Caliphate History and Legacies, 1804-2004 Vol.2,(pp.149 -158). Kaduna, Nigeria; Arewa House Ahmadu Bello University Zaria.

Vanguard. (2011). Anger, Shock Greet Lavish Reception for Bode George. Vanguard Newspaper Editorial (March $1^{\text {st })}$

Weiner, M. (1976). Political Unification. NY: Longman, (Chapter 2).

\section{Periodicals}

Daily Trust Newspaper, Abuja, Nigeria

Leadership Daily Newspapers, Abuja, Nigeria

Leadership on Sunday, Abuja, Nigeria

Tell Magazine, Lagos, Nigeria

The Punch Newspaper, Lagos, Nigeria

Weekly Trust Newspaper, Abuja, Nigeria 